\title{
Intergrowth texture in Au-Ag-Te minerals from Sandaowanzi gold deposit, Heilongjiang Province: Implications for ore-forming environment
}

\author{
XU Hong*, YU YuXing, WU XiangKe, YANG LiJun, TIAN Zhu, GAO Shen \& WANG QiuShu \\ School of Earth Sciences and Resources, China University of Geosciences, Beijing 100083, China
}

Received January 16, 2012; accepted March 16, 2012; published online May 6, 2012

\begin{abstract}
Sandaowanzi gold deposit, Heilongjiang Province, is the only single telluride type gold deposit so far documented in the world, in which $90 \%$ of gold is hosted in gold-silver telluride minerals. Optical microscope observation, scanning electron microscope, electron probe and X-ray diffraction analysis identified abundant intergrowth textures in the Au-Ag-Te minerals, typified by sylvanite-hosting hessite crystals and hessite-hosting petzite crystals. The intergrown minerals and their chemistry are consistent, and the hosted minerals are mostly worm-like or as oriented stripes, evenly distributed in the hosting minerals, with clear and smooth interfaces. These suggest an exsolution origin for the intergrowth texture. With reference to the phase-transformation temperature derived from synthesis experiments of tellurides, the exsolution texture of Au-Ag-Te minerals implies that the veined tellurides formed at $150-220^{\circ} \mathrm{C}$. The early stage disseminated tellurides formed at $\log f\left(\mathrm{Te}_{2}\right)$ from -13.6 to $-7.8, \log f\left(\mathrm{~S}_{2}\right)$ from -11.7 to -7.6 , whereas the late stage veined tellurides formed at $\log f\left(\mathrm{Te}_{2}\right)$ ranging from -11.2 to -9.7 and $\log f\left(\mathrm{~S}_{2}\right)$ from -16.8 to -12.2 .
\end{abstract}

Sandaowanzi gold deposit, Au-Ag tellurides, intergrowth texture, mineralization environment

Citation: $\quad \mathrm{Xu} \mathrm{H}, \mathrm{Yu}$ Y X, Wu X K, et al. Intergrowth texture in Au-Ag-Te minerals from Sandaowanzi gold deposit, Heilongjiang Province: Implications for ore-forming environment. Chin Sci Bull, 2012, 57: 2778-2786, doi: 10.1007/s11434-012-5170-7

The Sandaowanzi gold deposit is a newly discovered epithermal-mesothermal telluride deposit, in which more than $90 \%$ of gold occur as telluride minerals, with gold grade up to $20000 \times 10^{-6}$. It is the only single telluride gold deposit ever documented in the world [1-3]. Tellurides are abundant in the Sandaowanzi gold deposit [1-4], including calaverite $\left(\mathrm{AuTe}_{2}\right)$, krennerite $\left((\mathrm{Au}, \mathrm{Ag}) \mathrm{Te}_{2}\right)$, petzite $\left(\mathrm{Ag}_{3} \mathrm{AuTe}_{2}\right)$, hessite $\left(\mathrm{Ag}_{2} \mathrm{Te}\right)$, coloradoite $(\mathrm{HgTe})$ and altaite $(\mathrm{PbTe})$, and possibly $\mathrm{Au}_{2} \mathrm{Te}$ compound as suggested by the research [5]. Intergrowth textures are commonly seen in the Au-Ag-Te tellurides, mostly as sylvanite-hessite and petzite-hessite.

$\mathrm{Au}-\mathrm{Ag}-\mathrm{Te}$ system is a very common intermetallic compound group. Previous authors have carried out extensive synthetic experiment research, which revealed the rel-

*Corresponding author (email: hongxu88@126.com) ationship among Au-Ag-Te mineral crystal chemistry, paragenetic association and the temperature under which the minerals were formed: (1) transformation temperature of the synthetic minerals: in the Ag-Te binary system the transition of hessite from lower crystal category into higher class takes place at $145 \pm 3^{\circ} \mathrm{C}$ [6-9]; for petzite in cubic system, the transition from low-temperature phase to hightemperature phase takes place at $210 \pm 10^{\circ} \mathrm{C}[8,10]$. (2) Under heating, petzite-hessite begins to form solid solution at $250^{\circ} \mathrm{C}$ [10]. Cabri [8], Markham [11,12] and Legendre [13] carried out respectively synthesis experiment of $\mathrm{Au}-\mathrm{Ag}-\mathrm{Te}$ system, of which Cabri's experiment was more successful, and he discussed the temperature for crystalization of the sythetic minerals and the phase-transformation. (3) Crystal chemistry: study of the crystal sturcture of natural Au-AgTe mineral series indentified incommensurate modulated texture and unique superspace texture [14-16]. Meanwhile, 
the crytal texture of telluride mineral are related to $\mathrm{Au}$ and Ag content [17,18], for example, crystal cell parameters $a_{0}$ and $c_{0}$ of calaverite increase with the increasing of $\mathrm{Ag}$ content [18]. Complex exsolution [19,20] and micrographic texuture [21] of tsumoite were also reported in the Dashuigou Te deposit, Sichuan Province. By means of optical microscope, scanning electron microscope, electron probe and X-ray diffraction analysis, we conducted detailed study on the intergrowth textures, and looked into the ore-forming environment of the telluride gold deposit.

\section{Ore deposit geology}

The Sandaowanzi telluride gold deposit is located at the northeastern edge of the Da Hinggan Mountains. Gold mineralization is hosted primarily by the early Cretaceous trachyte and trachytic andesite of Tamulangou Formation. The mining area is regionally controlled by NWW- and EW-striking faults, and the NWW-striking extensional faulting is the major ore-hosting structure [22,23].

Gold telluride ore bodies are primarily hosted in quartz veins intruding the Cretaceous trachyte andesite and trachytic andesitic breccias, secondly in silicified trachytic andesite. There are 40 ore bodies in three ore belts. Amongst them, the ore body II is the only ore body mined to date (Figure 1). The length of the lenticular ore body is $212.6 \mathrm{~m}$ at the surface and its thickness varies from 0.81 to $14.3 \mathrm{~m}$ with an average of about $6 \mathrm{~m}$. The transformation ratio of thickness is $59 \%$. The ore body strikes $20^{\circ}-40^{\circ}$ and dips $58^{\circ}-77^{\circ}$ northwestward (the angle becomes smaller in the deep, and the minimum is only $30^{\circ}$ ), plunging to $520 \mathrm{~m}$ in the dip direction. There are two horizons of high grade ores from 240 to $50 \mathrm{~m}$, ranging from $1 \times 10^{-6}$ to $20000 \times 10^{-6}$, and the highest grade is found at the $130 \mathrm{~m}$ horizon.

\section{Tellurides}

\subsection{The ore occurrences and mineralogy}

The tellurides mainly occur at the level from 90 to $130 \mathrm{~m}$, within the ore body of Sandaowanzi gold deposit, and are rare at other levels. The quantity of tellurides in the ore body exhibits a positive correlation with the gold grade that averages $99.38 \times 10^{-6}$ at the level from 90 to $130 \mathrm{~m}$, with the hightest grade up to $20000 \times 10^{-6}$. There are two major occurrence modes for the telluride gold ores in the deposit, veins and disseminations. Tellurides in the dissemination ores are dominated by hessite, petzite and sylvanite, frequently associated with sulfides, i.e. pyrite, chalcopyrite, tetrahedrite, galena and sphaleite. The tellurides in the vein-type ores mainly occur in 23 and 25 cross cuts at 130 $\mathrm{m}$ level of ore body, and the mineralogy is dominated by petzite, sylvanite, calaverite, native gold, and accidently a new compound $\mathrm{Au}_{2} \mathrm{Te}$ [5].

\subsection{The ore-forming stages}

Field observation and microscope study suggest that the ore-forming process may include three stages: (1) The early stage paragenesis include pyrite-quartz and polymetallic sulphides-quartz phases, hesite-dominated tellurides are rare in these assembledges. These ores are found at the level from 50 to $240 \mathrm{~m}$. (2) The second stage, dominated by

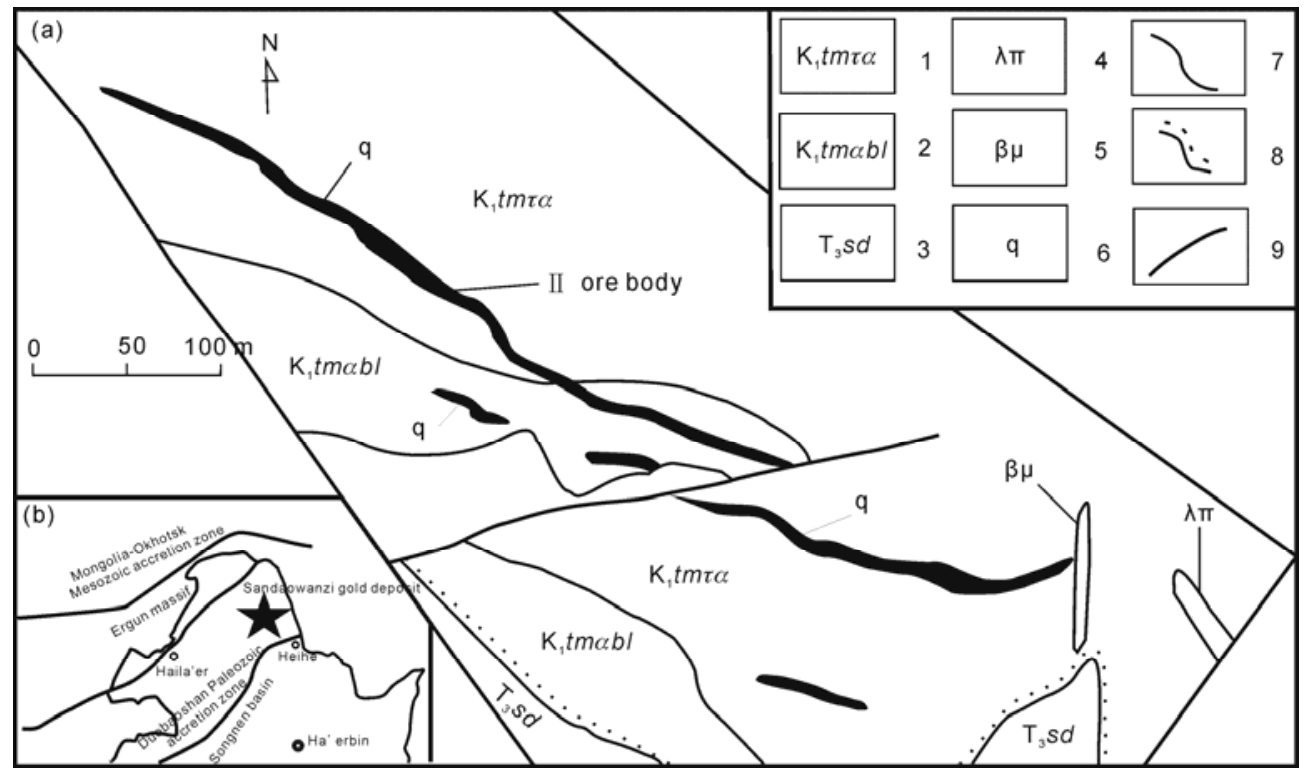

Figure 1 (a) The geological map of Sandaowanzi gold ore district (after Tran et al. [1] ); (b) tectonic map of Sandaowanzi gold deposit (after Tran et al. [1]). 1, Trachyandesite of Tamulangou Formation; 2, andesite breccia of Tamulangou Formation; 3, adamellite of Sandaowanzi Unit; 4, Early Cretaceous rhyolite porphyry; 5 , diabase porphyrite; 6 , Au-bearing quartz vein; 7 , geological boundary; 8 , unconformity boundary; 9 , fault. 
gold and silver tellurides, is the principal stage for gold mineralization, the ores from this stage are located at the level from 90 to $130 \mathrm{~m}$. Paragenetic and structural evidences further subdivided this stage into two phases: 1) the earlier phase is expressed by quartz-hosted tellurides disseminationsand the mineralogy is dominated by hessite, petzite and sylvanite, in which telluridesoccur in the form of clumpaggregate, and hessite commonly intergrows with sylvanite (Figure 2(a)); and 2) the later phase isexpressed by telluride veins cross cutting telluride disseminations. The mineralogy is dominated by petzite and sylvanite, and intergrowth of petzite with hessite (occasionally with coloradoite or calaverite). Minor native gold is found in the second stage ores, which occur in two modes: 1) round grains coexisting with calaverite and 2) round grains in the cracks of petzite, occasionally associated with round grains of the new compound $\mathrm{Au}_{2} \mathrm{Te}$. The late stage is expressed by carbonate-quartz veins with poor gold mineralization.

\section{The intergrowth among tellurides}

\subsection{Mineralogy}

Ore petrographic observation and Scanning Electron Microscope analysis (equipped with energy spectrum) have identified two types of intergrowth texture formed in the $\mathrm{Au}-\mathrm{Ag}$ tellurides mineralization. Type $\mathrm{I}$ is characterized by intergrowth of hessite with sylvanite, in which hessite is the host, and sylvanite occurs as drips and stripes dispersed in hessite (Figure 2(a)); type II, petzite intergrows with hessite that occurs mostly as warm-like or strips in hessite (Figure 2(b)), occasionally hosting calaverite and coloradoite (Figure 2(c)).
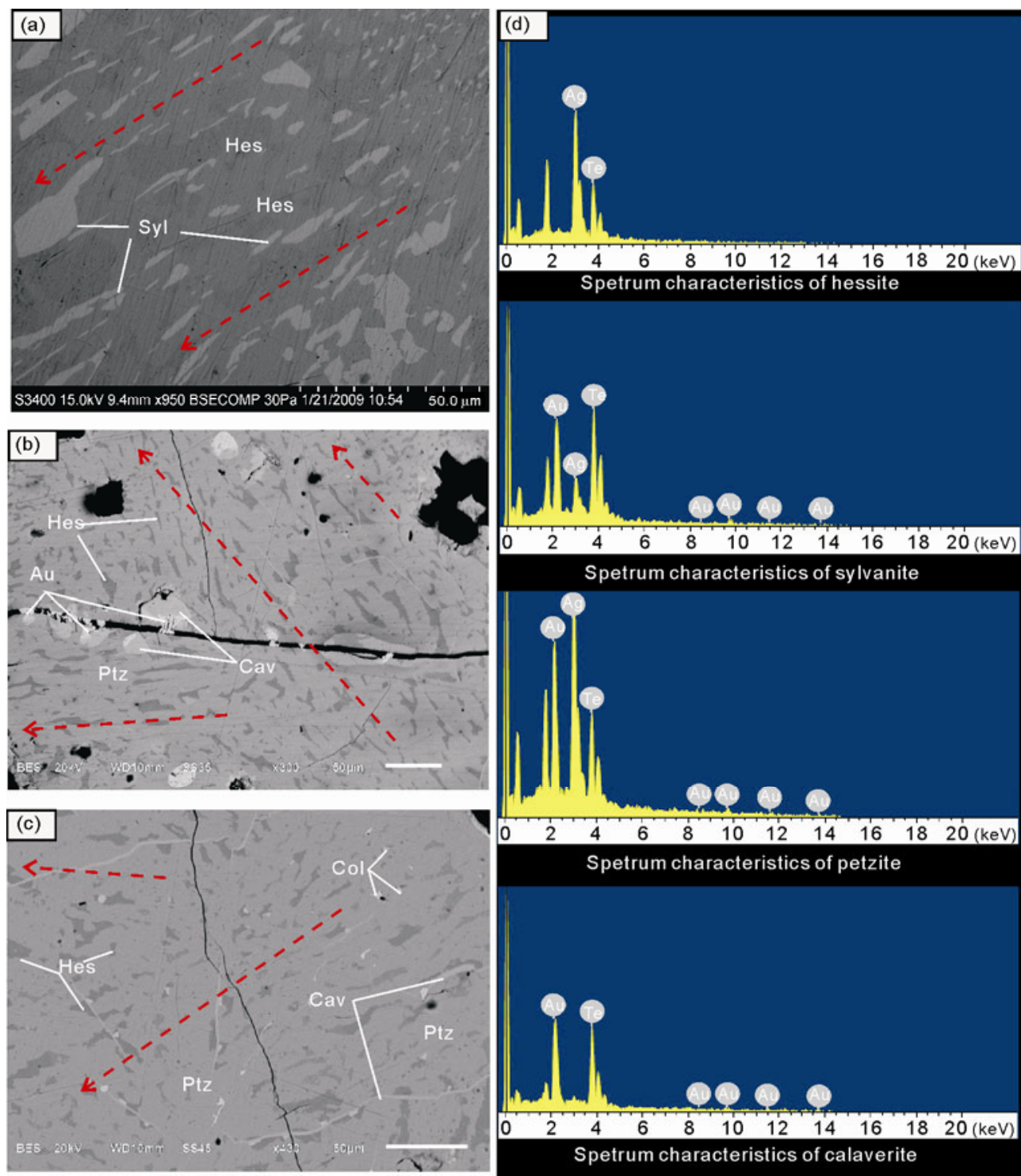

Figure 2 Typical intergrowth texutures in tellurides in Sandaowanzi gold deposit. (a) Sylvanite intergrown with hessite; (b) hessite intergrown with petzite; (c) hessite, calaverite and coloradoite intergrown with petzite; (d) typical spetrum characteristics of tellurides. Arrows show the orientation of the exsolusion. Syl, sylvanite; Hes, hessite; Cav, calaverite; Ptz, petzite; col, coloradoite; Au, native gold. 


\subsection{Morphology of the intergrowth}

In hessite-sylvanite intergrowth texture, sylvanite occurs as arrays of drips $(2-20 \mu \mathrm{m}$ in size) or stripes $(10-35 \mu \mathrm{m}$ in length and 2-5 $\mu \mathrm{m}$ in width) drip-like within hessite (Figures 2(a),3(a)). No sylvanite has been found outside hessite. The borders between the hosting and hosted minerals are smooth but show no evidence of replacement relationaship. Hessite by volume accounts for about $2 / 3$ of the intergrowth minerals, whereas sylvanite accounts for nearly $1 / 3$, suggesting $\mathrm{Ag}_{5} \mathrm{AuTe}_{6}$ for chemical formula of this intergrowth.

In petzite-hessite intergrowth texture, petzite hosts hessite, and the latter occurs only within the former, as stripes, 10-50 $\mu \mathrm{m}$ long and $2-10 \mu \mathrm{m}$ wide, never goes out of the host (Figures 2(b),3(b) and (c)). Also in the host include minor calaverite, as drips 50-150 $\mu \mathrm{m}$ long and about $3 \mu \mathrm{m}$ wide, and coloradoite, mineral grains as drips from 3 to 5 $\mu \mathrm{m}$ across (Figures 2(c),3(d)). Petzite by volume accounts for nearly $2 / 3$ of the intergrown minerals and hessite accounts for nearly $1 / 3$, based on which we infer that the chemical formula of this intergrowth is approximately $\mathrm{Ag}_{8} \mathrm{Au}_{2} \mathrm{Te}_{3}$.

In both intergrowth textures, the hosted minerals are aligned and evenly dispersed in the hosting minerals. The shapes of the margins between the hosting and hosted minerals do not support a metasomatism origin.

Hessite in the intergrowth texture shows strong heterogeneity, varying from dark orange to dark bluish grey-colored under ore microscope. This suggests that the hessite is monoclinic [24]. Hessite's structure varies between isometric and monoclinic in response to temperature change, and the transition point is $145 \pm 3^{\circ} \mathrm{C}$ [6-8].

\subsection{Chemistry of the intergrown minerals}

The chemistry of the ntergrown minerals were analyzed with scanning electron microscope equipped with energy spectrum and electron probe (Table 1). In type I of intergrowth texture, hosting and hosted minerals are hessite and sylvanite respectively. Based on the experiment data (Table 1), the content of $\mathrm{Ag}$ and $\mathrm{Te}$ in hessite are $60.63 \mathrm{wt} \%$ to $64.57 \mathrm{wt} \%$, averaging $62.09 \mathrm{wt} \%$ and $35.37 \mathrm{wt} \%$ to 39.37 $\mathrm{wt} \%$, averaging $37.89 \mathrm{wt} \%$, respectively. The content of $\mathrm{Ag}$, $\mathrm{Te}$ and $\mathrm{Au}$ in sylvanite are $12.44 \mathrm{wt} \%$ to $12.44 \mathrm{wt} \%$ (with an average of $14.19 \mathrm{wt} \%$ ), $57.39 \mathrm{wt} \%$ to $61.44 \mathrm{wt} \%$ (with an average of $59.75 \mathrm{wt} \%$ ) and $23.09 \mathrm{wt} \%$ to $29.32 \mathrm{wt} \%$ (with an average of $26.07 \mathrm{wt} \%$ ), respectively.
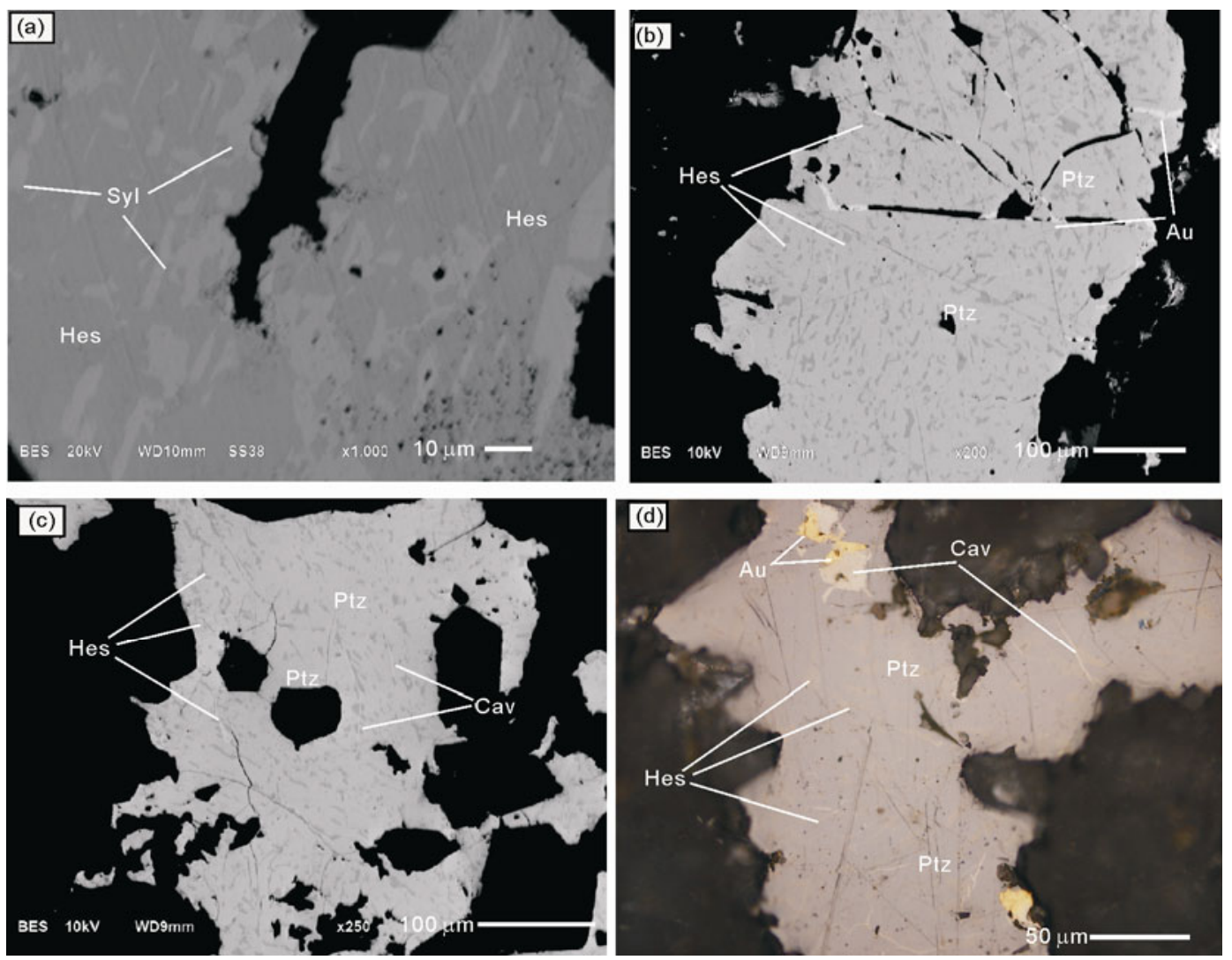

Figure 3 Typical intergrowth texutures in telluride minerals. (a) Sylvanite intergrown with hessite; (b), (c) hessite intergrown with petzite; (d) hessite and calaverite intergrown with petzite. Hes, Hessite; Cav, calaverite; Ptz, petzite; col, coloradoite; Au, native gold. 
Table 1 Chemical composition of the minerals in intergrowth textures (wt $\%)^{\text {a) }}$

\begin{tabular}{|c|c|c|c|c|c|c|c|c|c|c|c|c|c|c|c|c|}
\hline \multicolumn{2}{|c|}{ Intergowth type } & Number & $\mathrm{Se}$ & $\mathrm{Au}$ & $S$ & $\mathrm{Fe}$ & $\mathrm{Cu}$ & $\mathrm{Zn}$ & Co & $\mathrm{Ni}$ & $\mathrm{Ag}$ & $\mathrm{Te}$ & $\mathrm{Bi}$ & Total & $\begin{array}{l}\text { Chemical } \\
\text { formula }\end{array}$ & $\begin{array}{c}\text { Mineral } \\
\text { species }\end{array}$ \\
\hline \multirow{6}{*}{$\begin{array}{l}\text { Hessite-sylvanite } \\
\text { intergrowth } \\
\text { (by SEM) }\end{array}$} & \multirow{3}{*}{$\begin{array}{c}\text { Hosting } \\
\text { crystal }\end{array}$} & 1 & - & - & - & - & - & - & - & - & 60.63 & 39.37 & - & 100.00 & $\mathrm{Ag}_{2} \mathrm{Te}$ & \multirow{3}{*}{ hessite } \\
\hline & & 2 & - & - & - & - & - & - & - & - & 61.08 & 38.92 & - & 100.00 & $\mathrm{Ag}_{2} \mathrm{Te}$ & \\
\hline & & 3 & - & 0.06 & - & - & - & - & - & - & 64.57 & 35.37 & - & 100.00 & $\mathrm{Ag}_{2} \mathrm{Te}$ & \\
\hline & \multirow{3}{*}{$\begin{array}{l}\text { Hosted } \\
\text { crystal }\end{array}$} & 4 & - & 24.31 & - & - & - & - & - & - & 15.54 & 60.15 & - & 100.00 & $\mathrm{AuAgTe}_{4}$ & \multirow{3}{*}{ sylvanite } \\
\hline & & 5 & - & 29.32 & - & - & - & - & - & - & 13.30 & 57.39 & - & 100.00 & $\mathrm{AuAgTe}_{4}$ & \\
\hline & & 7 & - & 23.09 & - & - & - & - & - & - & 15.47 & 61.44 & - & 100.00 & $\mathrm{AuAgTe}_{4}$ & \\
\hline \multirow{18}{*}{$\begin{array}{l}\text { Petzite-hessite } \\
\text { intergrowth } \\
\text { (by EPMA) }\end{array}$} & \multirow{7}{*}{$\begin{array}{l}\text { Hosting } \\
\text { crystal }\end{array}$} & 1 & 0.15 & 25.27 & - & - & - & - & - & 0.00 & 41.43 & 32.58 & 0.19 & 99.63 & $\mathrm{AuAg}_{3} \mathrm{Te}_{2}$ & \multirow{7}{*}{ petzite } \\
\hline & & 2 & 0.01 & 24.57 & - & - & - & 0.08 & - & - & 40.72 & 32.68 & 0.38 & 98.43 & $\mathrm{AuAg}_{3} \mathrm{Te}_{2}$ & \\
\hline & & 3 & 0.07 & 25.02 & 0.00 & - & - & 0.02 & 0.01 & - & 41.49 & 32.66 & 0.38 & 99.66 & $\mathrm{AuAg}_{3} \mathrm{Te}_{2}$ & \\
\hline & & 4 & 0.15 & 24.93 & - & - & 0.01 & 0.05 & - & - & 41.14 & 32.77 & 0.47 & 99.51 & $\mathrm{AuAg}_{3} \mathrm{Te}_{2}$ & \\
\hline & & 5 & 0.13 & 24.88 & - & - & 0.03 & - & 0.02 & - & 41.28 & 32.41 & 0.10 & 98.84 & $\mathrm{AuAg}_{3} \mathrm{Te}_{2}$ & \\
\hline & & 6 & 0.04 & 25.00 & 0.01 & - & - & - & 0.00 & - & 40.70 & 32.56 & 0.15 & 98.46 & $\mathrm{AuAg}_{3} \mathrm{Te}_{2}$ & \\
\hline & & 7 & 0.12 & 24.89 & - & 0.01 & - & - & 0.02 & - & 41.19 & 32.34 & 0.33 & 98.90 & $\mathrm{AuAg}_{3} \mathrm{Te}_{2}$ & \\
\hline & \multirow{11}{*}{$\begin{array}{l}\text { Hosted } \\
\text { crystal }\end{array}$} & 8 & 0.20 & 1.64 & 0.01 & - & 0.02 & 0.05 & - & 0.02 & 57.44 & 40.40 & 0.06 & 99.82 & $\mathrm{Ag}_{2} \mathrm{Te}$ & \multirow{11}{*}{ hessite } \\
\hline & & 9 & 0.09 & 0.45 & 0.02 & - & 0.00 & 0.02 & - & 0.00 & 57.84 & 40.57 & 0.01 & 99.00 & $\mathrm{Ag}_{2} \mathrm{Te}$ & \\
\hline & & 10 & 0.18 & 0.36 & 0.01 & 0.01 & 0.03 & - & - & 0.03 & 58.54 & 40.56 & 0.06 & 99.77 & $\mathrm{Ag}_{2} \mathrm{Te}$ & \\
\hline & & 11 & 0.18 & 0.24 & 0.03 & 0.03 & 0.02 & 0.03 & 0.02 & 0.02 & 58.96 & 40.54 & 0.01 & 100.08 & $\mathrm{Ag}_{2} \mathrm{Te}$ & \\
\hline & & 12 & 0.15 & 0.43 & 0.01 & 0.07 & - & - & 0.03 & - & 58.21 & 40.64 & 0.00 & 99.54 & $\mathrm{Ag}_{2} \mathrm{Te}$ & \\
\hline & & 13 & 0.26 & 0.92 & 0.01 & 0.01 & - & - & - & - & 57.68 & 40.48 & 0.04 & 99.40 & $\mathrm{Ag}_{2} \mathrm{Te}$ & \\
\hline & & 14 & 0.18 & 0.67 & 0.01 & 0.01 & - & - & - & - & 58.39 & 40.03 & 0.04 & 99.32 & $\mathrm{Ag}_{2} \mathrm{Te}$ & \\
\hline & & 15 & 0.16 & 0.63 & 0.02 & 0.04 & 0.01 & 0.05 & - & 0.01 & 58.68 & 40.85 & 0.02 & 100.46 & $\mathrm{Ag}_{2} \mathrm{Te}$ & \\
\hline & & 16 & 0.19 & 40.48 & - & - & - & - & - & 0.02 & 1.48 & 55.86 & 0.76 & 98.78 & $\mathrm{AuTe}_{2}$ & \\
\hline & & 17 & 0.20 & 41.88 & - & 0.02 & - & 0.04 & - & 0.01 & 1.28 & 54.72 & 0.66 & 98.79 & $\mathrm{AuTe}_{2}$ & \\
\hline & & 18 & 0.06 & 41.38 & - & 0.03 & 0.01 & - & 0.00 & 0.01 & 1.30 & 55.01 & 0.67 & 98.46 & $\mathrm{AuTe}_{2}$ & \\
\hline
\end{tabular}

a) Testing units: Scanning electron microscope: University of Science and Technology Beijing. Electron probe: Mineral Resources Geology in Chinese Academy of Geosciences. Instrument types: JXA-8230; acceleration voltage: $20 \mathrm{kV}$; bean current: $20 \mathrm{nA}$; beam diameter: 1 or $5 \mu$ m; the standards used for calibration: $\mathrm{Pd} / \mathrm{Au}$ alloy for $\mathrm{Au}$; $\mathrm{AgS}$ for $\mathrm{Ag}$; $\mathrm{HgTe}$ for Te; $\mathrm{CuFeS}_{2}$ for $\mathrm{Fe}, \mathrm{Cu}$ and $\mathrm{S}$; FeAsS, $\mathrm{Sb}_{2} \mathrm{~S}_{3}, \mathrm{PbS}$ and $\mathrm{ZnS}$ for $\mathrm{As}, \mathrm{Sb}, \mathrm{Pb}$ and $\mathrm{Zn}, \mathrm{respectively}$. Below the inspecting line.

In type II intergrowth texture, petzite hosts in most cases hessite, occasionally calaverite and coloradoite. The petzite contains $40.70 \mathrm{wt} \%$ to $41.49 \mathrm{wt} \% \mathrm{Ag}$ (averaging 41.14 $\mathrm{wt} \%$ ), $32.34 \mathrm{wt} \%$ to $32.77 \mathrm{wt} \%$ Te (averaging $32.57 \mathrm{wt} \%$ ) and $24.57 \mathrm{wt} \%$ to $25.27 \mathrm{wt} \% \mathrm{Au}$ (averaging $24.94 \mathrm{wt} \%$ ). The content of $\mathrm{Ag}$, Te and $\mathrm{Au}$ in hessite are $57.44 \mathrm{wt} \%$ to $58.96 \mathrm{wt} \%$ (averaging $58.21 \mathrm{wt} \%$ ), $40.03 \mathrm{wt} \%$ to $40.85 \mathrm{wt} \%$ (averaging $40.51 \mathrm{wt} \%$ ) and $0.24 \mathrm{wt} \%$ to $1.64 \mathrm{wt} \%$ (averaging $0.67 \mathrm{wt} \%$ ), respectively. The content of $\mathrm{Ag}$, $\mathrm{Te}$ and $\mathrm{Au}$ in calaverite are $1.28 \mathrm{wt} \%$ to $1.48 \mathrm{wt} \%$ (averaging 1.35 wt $\%$ ), $54.72 \mathrm{wt} \%$ to $55.86 \mathrm{wt} \%$ (averaging $55.20 \mathrm{wt} \%$ ) and $40.48 \mathrm{wt} \%$ to $41.88 \mathrm{wt} \%$ (averaging $41.25 \mathrm{wt} \%$ ), respectively.

The atomic ratio of $\mathrm{Au}, \mathrm{Ag}$ and $\mathrm{Te}$ in the intergrowth minerals are ploted in Au-Ag-Te diagram (Figure 4), which indicates that the chemistry of the hosting and hosted mineral are stable. For hessite, only a few analysis are compatible with the theoretical stoichiometry $(\mathrm{Ag} / \mathrm{Te}=2 / 1)$, in most cases the content of tellurium is higher than theoretical stoichiometry. And the sylvanite has higher gold content than theoretical stoichiometry.

\subsection{X-ray diffraction analysis}

In order to determine the phases and cell parameters of the intergrown minerals, micro-zone X-ray diffraction and single-crystal X-ray diffraction were used on the basis of ore microscope observation, electron probe and scanning electron microscope analysis.

Micro-zone X-ray diffraction. The data of micro-zone $\mathrm{X}$-ray diffraction was collected by a Rigaku D/max Rapid IIR $18 \mathrm{KW}$ Rotating anode micro-zone diffraction at the reseach center of X-ray diffraction of Central South University. The working condition was $45 \mathrm{kV}$ and $35 \mathrm{~mA}$ with an $\mathrm{X}$-ray beam diameter of $30 \mu \mathrm{m}$. The data was collected after $2 \mathrm{~h}$ and the $2 \theta$ ranged from $20^{\circ}$ to $160^{\circ}$. The accuracy rating of $d$-values is higher than $0.001 \AA$.

With the consideration that the powder samples for X-ray diffraction analysis may contain impurities, micro-zone X-ray diffraction was applied. Sample 130CM23-13, derived from the vein type telluride ores has intergrowth texture. The detect zones are presented in Figure 5 and the micro-zone X-ray diffraction data are listed in Table 2. The 


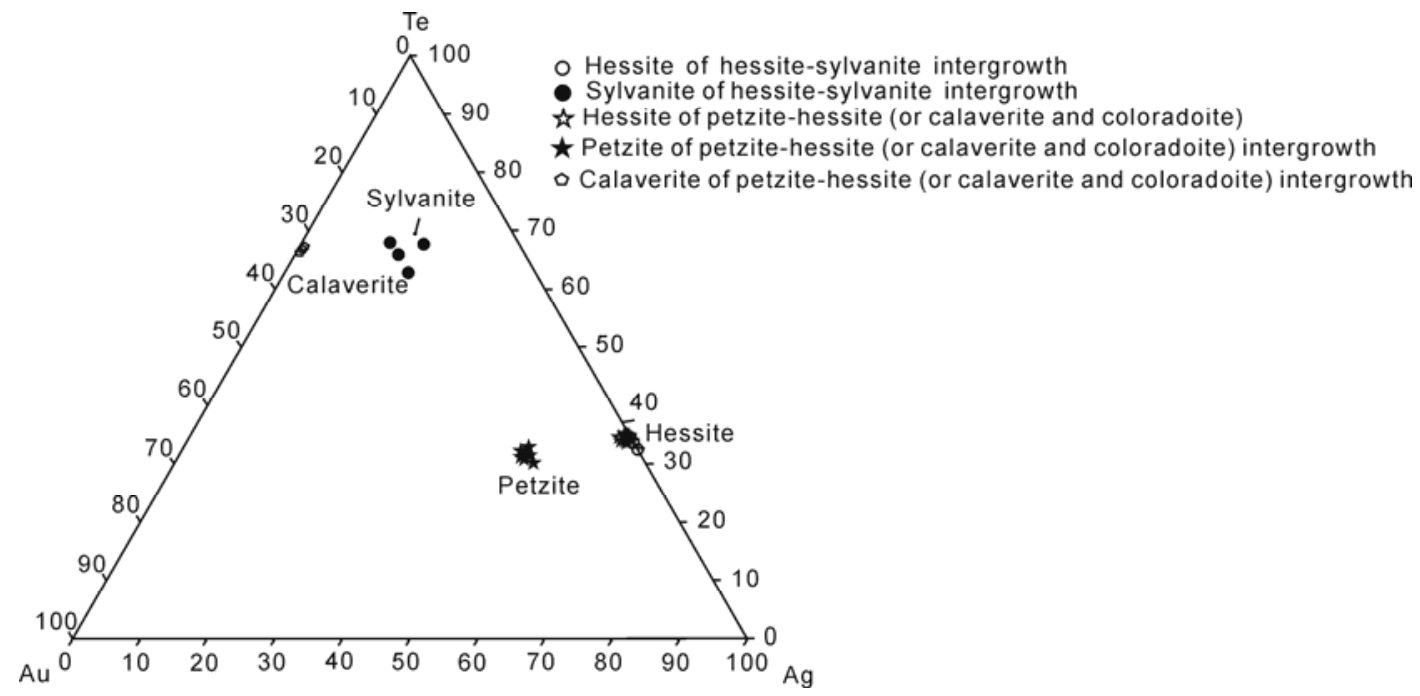

Figure 4 Tenary diagram of the intergrown minerals.
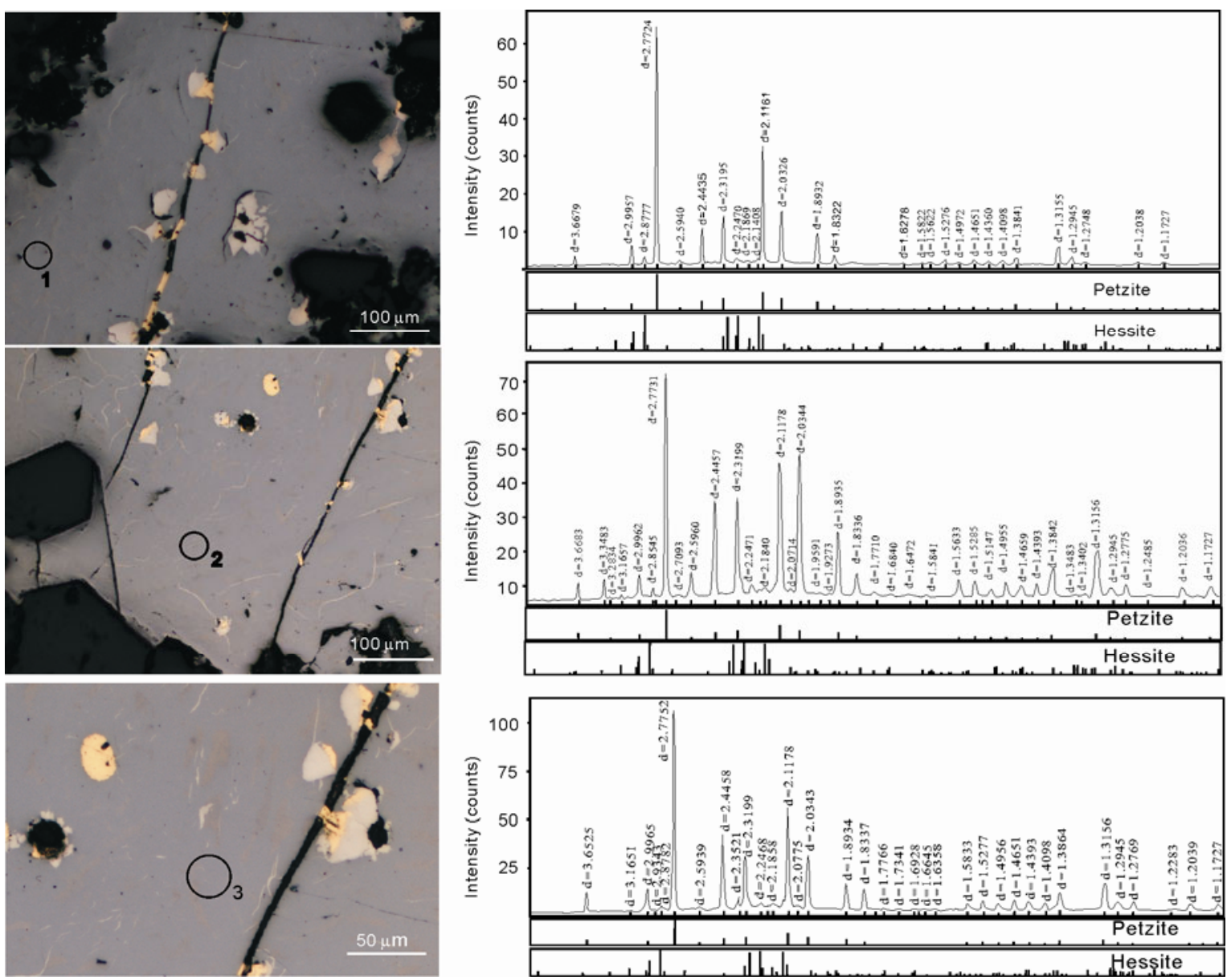

Figure 5 Micro-zone X-ray diffraction pattern of the intergrown minerals.

results indicate that the intergrown minerals are mostly petzite and hessite (Figure 5), which is consistent with the chemistry of the minerals determined by scanning electron microscope and electron probe.
Four crystals (also derived from sample 130CM23-13) were detected with single-crystal X-ray diffraction, on Bruker AXS SMART APEX diffractometer equipped with a $\mathrm{CCD}$ detector, working at $45 \mathrm{kV}$ and $35 \mathrm{~mA}$, at the State 
Key Laboratory of Geological Processes and Mineral Resources, China University of Geosciences (Beijing). A hemisphere of data was collected with graphite-monochromatized $\operatorname{MoK} \alpha(\lambda=0.71073 \AA)$ radiation and frame widths of $0.3^{\circ}$ in $\omega, 10 \mathrm{~s}$ per frame exposure time, at room temperature.

Petzite transforms from low-temperature phase $\left(a_{0}=10.38\right.$ $\AA)$ of isometric system to high-temperature phase $\left(a_{0}=5.20\right.$ $\AA$ ) of isometric system at $210 \pm 10^{\circ} \mathrm{C}[8,10]$, so the cell parameter of petzite can serve as an indicator of the crystallization temperature. The analysis of the four crystals yielded $10.39 \AA, 10.38 \AA, 103.9 \AA$ and $10.41 \AA$, respectively, averaging $10.39 \AA$ (Table 3 ). The results indicate that the petzite belongs to the low-temperature phase [9], and its crystallization temperature is lower than phase transition point $210 \pm 10^{\circ} \mathrm{C}$.

\section{Discussion and conclusions}

\subsection{Discussion}

(1) Genesis of the intergrowth textures in tellurides. In the above intergrowth textures, the hosted mineral exhibit alignment and are evenly distributed within the host minerals. The chemistry and mineralogy are persistent in the intergrowth textures. The morphology of the hosted crystal does not support a metasomatic origin. From the above evidence, the authors suggest an exsolution origin for the intergrowth textures. Hence the exsolution intergrowth texture can serve as an indicator for ore-forming environment, such as temperature, telluriun and sulfur fugacity.

(2) Constraints of mineralization temperature. (i) Evidence from paragenetic association. The petzite-hessite intergrowth paragenesis includes tellurides of petzite, hessite and calaverite and rarely native gold that is stable with calaverite (Figures 2(b),3(d)). Native silver was not discovered. With reference to the stability diagram of AuAg-Te-minerals (Figure 6) [25], the petzite-hessite-native gold and calaverite-native gold parageneses are stable at $150-280^{\circ} \mathrm{C}$.

(ii) Evidence from exsolution. Heating experiments of petzite-hessite stock have revealed that the minerals begin to form solid solution at $250^{\circ} \mathrm{C} \mathrm{[10]}$. Therefore we infer that the petzite-hessite intergrowth formed below $250^{\circ} \mathrm{C}$. Hessite shows strong heterogeneity (varing from dark orange to dark bluish grey) under a microscope, which suggests that the hessite is monoclinic rather than isometric. Synthesis experiments suggest that hessite transforms from isometric to monoclinic system at $145 \pm 3^{\circ} \mathrm{C}$ [6-9], therefore we infer that the crystallization temperature of hessite is below $145^{\circ} \mathrm{C}$. Combinations of the above arguments support the interpretation that the petzite-hessite intergrowth was formed below $250^{\circ} \mathrm{C}$, as the hessite might have transformed from isometric system to monoclinic system afer exsolution.

(iii) Significance of cell parameters of petzite for temperature indicating. The cell parameter of petzite is $10.38 \AA$, which indicates that the petzite belongs to the low temperature form of isometric system $[8,10]$. We can infer that the crystallization temperature of petzite is below $210 \pm 10^{\circ} \mathrm{C}$, the transition point for petzite from low temperature form of isometric system to high-temperature form of isometric system.

All the above analysis suggest that the petzite-hessite intergrowth texture formed at $150-220^{\circ} \mathrm{C}$, and the monoclinic hessite might have been formed below $145^{\circ} \mathrm{C}$. The texture is always observed in vein ores that represents the late phase

Table 2 The micro-zone X-ray diffraction data of petzite

\begin{tabular}{|c|c|c|c|c|c|c|c|}
\hline \multicolumn{2}{|c|}{ 130CM23-13-1 } & \multicolumn{2}{|c|}{ 130CM23-13-2 } & \multicolumn{2}{|c|}{ 130CM23-13-3 } & \multicolumn{2}{|c|}{ JCPDS12-424 (petzite) } \\
\hline$d(\AA)$ & $I / I^{\prime}$ & $d(\AA)$ & $I / I^{\prime}$ & $d(\AA)$ & $I / I^{\prime}$ & $d(\AA)$ & $I / I^{\prime}$ \\
\hline 2.77 & 100 & 2.77 & 100 & 2.78 & 100 & 2.77 & 100 \\
\hline 2.12 & 49 & 2.03 & 63 & 2.12 & 49 & 2.12 & 80 \\
\hline 2.03 & 22 & 2.12 & 58 & 2.45 & 38 & 2.03 & 70 \\
\hline 2.32 & 20 & 2.32 & 44 & 2.03 & 27 & 2.32 & 60 \\
\hline 2.44 & 15 & 2.45 & 42 & 2.32 & 26 & 2.44 & 60 \\
\hline 1.89 & 13 & 1.89 & 29 & 1.89 & 13 & 1.89 & 50 \\
\hline 1.32 & 8 & 1.38 & 11 & 3.00 & 11 & 1.31 & 50 \\
\hline
\end{tabular}

Table 3 Cell parameters of petzite in sandaowanzi gold deposit

\begin{tabular}{|c|c|c|c|c|c|}
\hline & Samples & 130CM23-13-a & 130CM23-13-b & 130CM23-13-c & 130CM23-13-d \\
\hline \multirow{4}{*}{$\begin{array}{l}\text { Sandaowanzi } \\
\text { gold deposit }\end{array}$} & Formulas & $\mathrm{AuAg}_{3} \mathrm{Te}$ & $\mathrm{AuAg}_{3} \mathrm{Te}$ & $\mathrm{AuAg}_{3} \mathrm{Te}$ & $\mathrm{AuAg}_{3} \mathrm{Te}$ \\
\hline & & $a_{0}=10.39 \AA$ & $a_{0}=10.38 \AA$ & $a_{0}=10.39 \AA$ & $a_{0}=10.41 \AA$ \\
\hline & Cell parameters & $b_{0}=10.39 \AA$ & $b_{0}=10.38 \AA$ & $b_{0}=10.39 \AA$ & $b_{0}=10.41 \AA$ \\
\hline & & $c_{0}=10.39 \AA$ & $c_{0}=10.38 \AA$ & $c_{0}=10.39 \AA$ & $c_{0}=10.41 \AA$ \\
\hline \multirow{2}{*}{ Synthetic petzite $[8,10]$} & High-temparation form & \multicolumn{4}{|c|}{ Isometric system $a_{0}=5.20 \AA$} \\
\hline & Low-temparation form & \multicolumn{4}{|c|}{ Isometric system $a_{0}=10.38 \AA$} \\
\hline
\end{tabular}




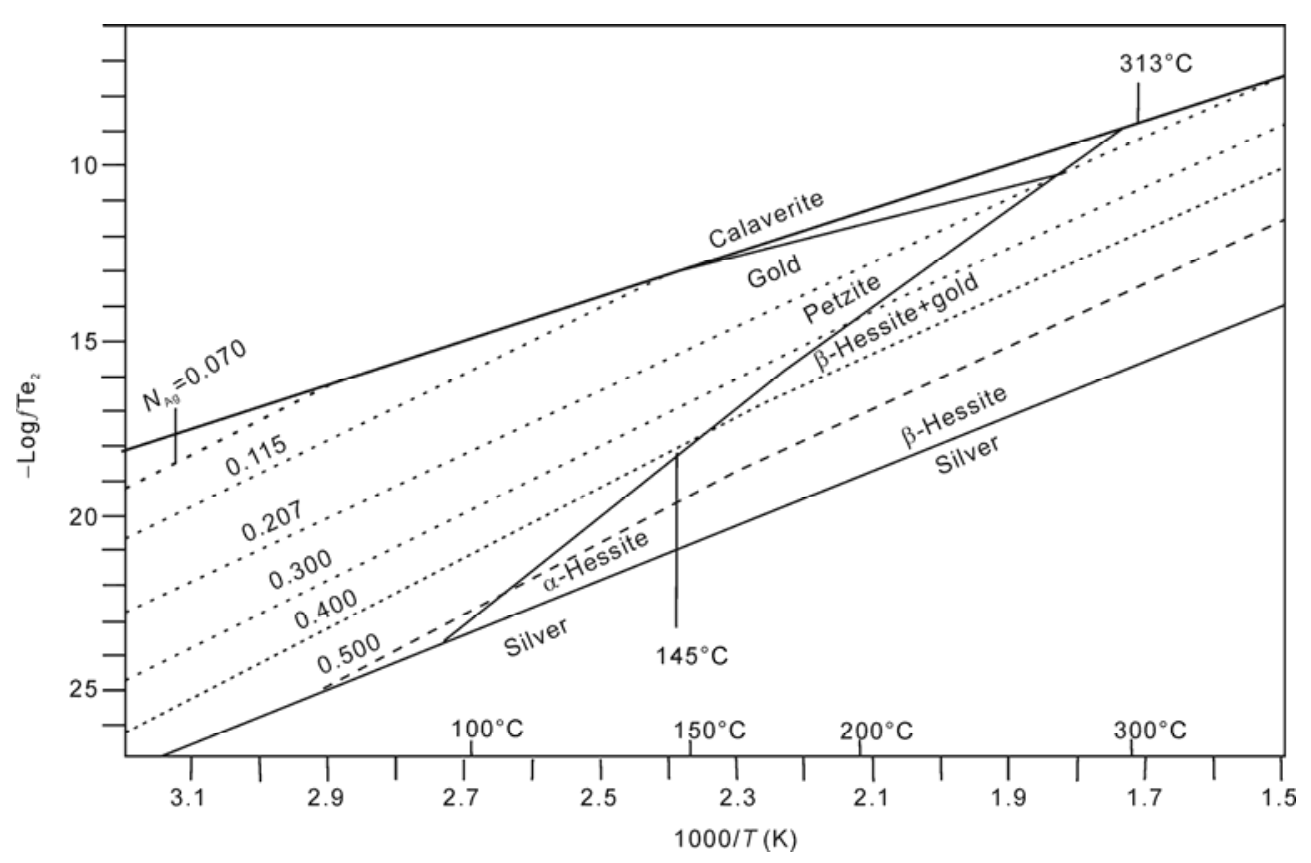

Figure 6 Stability diagram of Au-Ag-Te-minerals (after Bortnikov et al. [25]).

in the stage of Au-Ag telluride mineralization. The crystallization temperature of the intergrown minerals may represent the ore-forming temperature of the late phase of the $\mathrm{Au}-\mathrm{Ag}$ tellurides stage. Previous fluid inclusion study of quartz from the Au-Ag tellurides yielded homogeneous temperature ranging from $220-320^{\circ} \mathrm{C}$ [2]. The lower limit temperature from the fluid inclusion study may correlate with the the upper limit temperature of this study.

(3) Telluriun fugacity. With reference to the crystallization temperature data, we can discuss the telluriun fugacity in the ore forming process. The $\mathrm{Au}-\mathrm{Ag}$ telluride mineralization process could be divided into two phases, i.e. the early dissemination ores and the late vein ores. The dissemination ores mainly contain tellurides, mostly hessite, sylvanite, petzite and minor altaite. The tellurides from this stage may coexist with sulfides, but native silver and calaverite have not been discovered. The hessite-sylvanite intergrowth texture is observed in minerals from this phase. On the basis of the homogeneous temperature $\left(220-320^{\circ} \mathrm{C}\right)$ [2] and the stabilities of sulfides and tellurides as a function of $f\left(\mathrm{Te}_{2}\right)$ and $f\left(\mathrm{~S}_{2}\right)$ (Figure 7) [26], we infer $\log f\left(\mathrm{Te}_{2}\right)-13.6$ to -7.8 and $\log f\left(\mathrm{~S}_{2}\right)-11.7$ to -7.6 for the early phase dissemination ores (at $300^{\circ} \mathrm{C}$ ). Petzite-hessite intergrowth texture discussed in this paper is found in the late phase vein type ores of the Au-Ag telluride mineralization. It formed below $220^{\circ} \mathrm{C}$, dominated in mineralogy by petzite, hessite and calaverite. With reference to the stabilities of sulfides and tellurides as a function of $f\left(\mathrm{Te}_{2}\right)$ and $f\left(\mathrm{~S}_{2}\right)$ at $200^{\circ} \mathrm{C}$ (Figure 8) [27], we infer $\log f\left(\mathrm{Te}_{2}\right)-11.2$ to -9.7 , and $\log f$ $\left(\mathrm{S}_{2}\right)-16.8$ to -12.2 for the later phase dissemination ores. All the evidence suggests that telluriun fugacity increased in

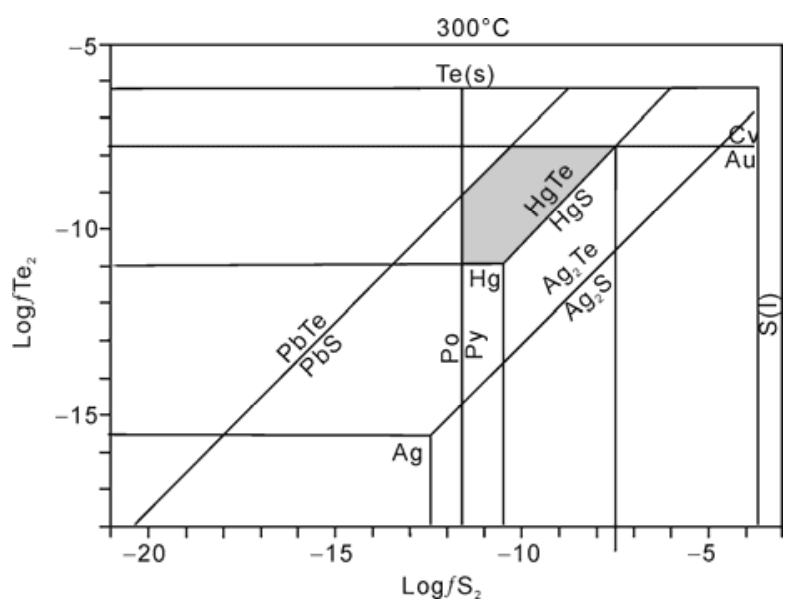

Figure 7 The stabilities of sulfides and tellurides as a function of $f\left(\mathrm{~S}_{2}\right)$ and $f\left(\mathrm{Te}_{2}\right)$ at $300^{\circ} \mathrm{C}$ (after Afifi et al. [26]).

the mineralization, matched with decline of sulfur fugacity.

\subsection{Conclusions}

(1) The intergrowth textures are common in the Au-Ag tellurides in Sandaowanzi gold deposit. The intergrown minerals could be divided into two groups: sylvanite-hessite and petzite-hessite (coloradoite-calaverite). We propose an exsolution interpretation for the genesis of the intergrowth textures, which is supported by the morphologies of the textures, distribution patterns of the chadacryst mineral and mineral chemistry. Significantly, the intergrowth textures could provide ore-forming information of the Au-Ag telluride deposit.

(2) The petzite-hessite (or calaverite and coloradoite) in 


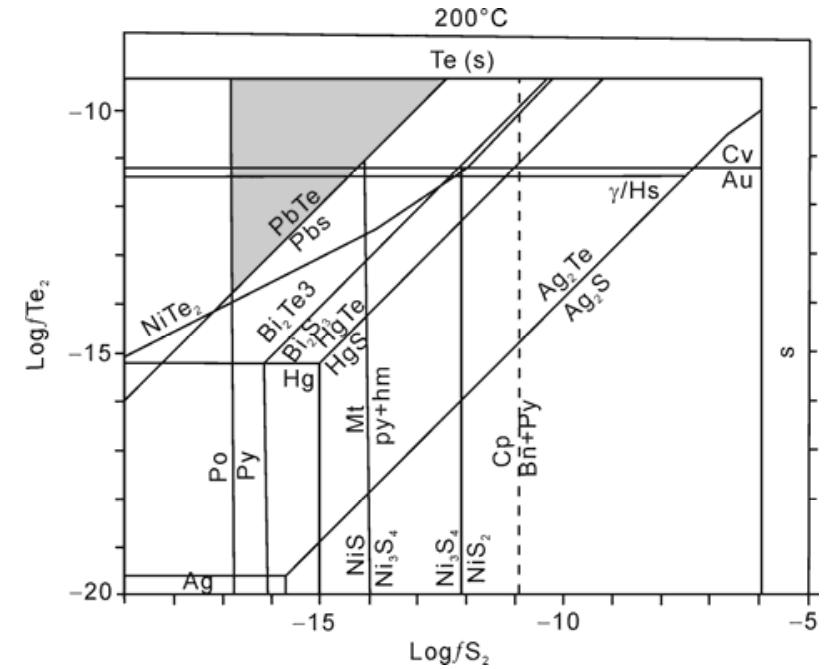

Figure 8 The stabilities of sulfides and tellurides as a function of $f\left(\mathrm{~S}_{2}\right)$ and $f\left(\mathrm{Te}_{2}\right)$ at $200^{\circ} \mathrm{C}$ (after Afifi et al. [27]).

tergrowth texture may have formed below $220^{\circ} \mathrm{C}$, as evidenced by experimental exsolution temperature and crystal structure of the intergrown minerals.

(3) Disseminated tellurides were formed under $\log f\left(\mathrm{Te}_{2}\right)$ from -13.6 to -7.8 and $\log f\left(\mathrm{~S}_{2}\right)$ from -11.7 to -7.6 in the earlier phase gold-silver tellurides. Veined tellurides formed under $\log f\left(\mathrm{Te}_{2}\right)$ from -11.2 to -9.7 and $\log f\left(\mathrm{~S}_{2}\right)$ from -16.8 to -12.2 in the later phase gold-silver tellurides.

The study of exsolution in Au-Ag-Te minerals from Sandaowanzi gold deposit can provide direct mineralization information, especially the physicochemical conditions of ore-forming processes. The research results have significance for understanding ore genesis and providing guidence to mineral exploration.

The Heilongjiang Provincial Bureau for Geology and Mineral Exploration has provided strong support to the project, and the authors are especially grateful to Yu Yuanbang and Wang Hongbo for their help during the field work. Branch of Geological Survey of Heilongjiang Province at Qiqiha'er and the Sandaowanzi Glod of Heilongjiang Province Limited Company also provided support to the research. Li Guowu, Chen Zhenyu and Gu Xiangping helped in processing of Single-crystal X-ray analysis, Electron Probe analysis and Micro-zone X-ray diffraction, which is gratefully recognized. This work was supported by the Project of China Geological Survey (1212011121083) and the Public Industry Research and Development Program of the Ministry of Land and Resources (200811011).

1 Tran M D, Liu J L, Hu J J, et al. Discovery and geological significance of Sandaowanzi telluride type gold deposit in the northern Daxing'anling, Heilongjiang, China (in Chinese). Geol Bull Chin, 2008, 27: 584-587

2 Zhao S J, Liu J L, Bai X D, et al. Fluid inclusions and sulfur isotopes of Sandaowanzi gold telluride deposit, Heilongjiang Province (in Chinese). Miner Dep, 2010, 29: 476-488

3 Liu J L, Bai X D, Zhao S J, et al. Geology of the Sandaowanzi telluride gold deposit of the northern Da Hinggan Mountains, NE China:
Geochronology and tectonic controls. J Asian Earth Sci, 2011, 41: 107-118

4 Han S Y, Zhai D G, Liu J J, et al. Mineral assemblage of Sandaowanzi tellurium-gold depositin Heilongjiang Province and its genetic significanc (in Chinese). Miner Dep, 2011, 30: 855-866

$5 \mathrm{Xu} \mathrm{H}, \mathrm{Yu} \mathrm{Y} \mathrm{X,} \mathrm{Gao} \mathrm{S,} \mathrm{et} \mathrm{al.} \mathrm{A} \mathrm{new} \mathrm{crystalline} \mathrm{compounds} \mathrm{of} \mathrm{Au-Te}$ in Sandaowanzi gold deposit, Heilongjiang Province (in Chinese). Geol Bull Chin, 2011, 30: 1779-1784

6 Frueh A J. The structure of hessire, $\mathrm{Ag}_{2}$ Te-III. Zeitschrift für Krist, 1959, 112: 44-52

7 Sharma S K. Transformation of structure in silver-tellurium alloy films. Nature, 1963, 198: 280-281

8 Cabri L J. Phase relations in the Au-Ag-Te system and their mineralogical significance. Econ Geol, 1965, 60: 1569-1609

9 Kracek F C, Cabri L J. Phase relations in the system tellurium-silver system. Am Mineral, 1966, 51: 14-18

10 Frueh A J. The crystallography of petzite, $\mathrm{Ag}_{3} \mathrm{Au}_{2} \mathrm{Te}$. Am Mineral, 1959, 44: 693-701

11 Markham N L. Synthetic and natural phases in the system Au-Ag-Te. Part I. Econ Geol, 1960, 55: 1148-1178

12 Markham N L. Synthetic and natural phases in the system Au-Ag-Te. Part II. Econ Geol, 1960, 55: 1460-1477

13 Legendre B, Souleau C, Chhay H. The ternary system Au-Ag-Te. Bull Soc Chim France, 1980, 5: 197-204

14 Luo H L, Klement W J. Metastateble simple cubic structures in gold-tellurium and silver-tellurium alloys. J Chem Phys, 1962, 36: 1870-1874

15 Tendeloo G V, Gregoriades P, Amelinckx S. Electron microscopic studies of modulated structures in (Au, Ag) Te 2 II. Sylvanite AgAuTe A $_{4}$ J Solid State Chem, 1983, 50: 335-361

16 Pertlik F. Crystal chemistry of natural Tellurides II: Redetermination of the crystal structure of Krennerite, $\left(\mathrm{Au}_{1-x} \mathrm{Ag}_{x}\right) \mathrm{Te}_{2}$ with $x \sim 0.2$. TEMP Tschermark Min Petr Mitt, 1984, 33: 253-262

17 Wagner F, Sawicki J, Friedl J, et al. ${ }^{194}$ Au Moossbauer study of the gold-silver ditellurides sylvanite, krennerite and calaverite. Can Mineral, 32: 189-201

18 Luca B, Alla A, Gervais C. The role of silver on the stabilization of the incommensurately modulated structure in calaverite, $\mathrm{AuTe}_{2}$. Am Mineral, 2009, 94: 728-736

19 Wang R C, Chen X M, Xu S J, et al. Complex exsolution in Te minerals from the Dashuigou Te deposit (in Chinese). Chin Sci Bull (Chin Ver), 1996, 41: 920-922

20 Wang R C, Chen X M, Xu S J, et al. Complex exsolution in Te minerals from the Dashuigou Te deposit. Chin Sci Bull, 1996, 41: 11981202

21 Zhang P H, Zhao Z H, Wang Y X, et al. New evidence for the metasomatism of graphic-myrmekitic textures of tsumoite in the Dashuigou tellurium deposit (in Chinese). Geol Rev, 2000, 46: 318-323

22 Lv J, Yue B J, Wang J M, et al. Characteristics and prospecting in dicators of the Sandaowanzi gold deposit in Heihe City, Heilongjiang Province (in Chinese). Geol Resour, 2005, 14: 256-260

23 Teng X F, Wang J M, Wang C P, et al. Geological characteristics of the Sandaowanzi gold deposit in Heihe City, Heilongjiang Province (in Chinese). Geol Resour, 2005, 14: 261-264

24 Lu J W, Peng X L. Handbook of Ore Microscope Identification (in Chinese). Beijing: Geological Publishing House, 2010

25 Bortnikov N S, Kramer K, Genkin A D, et al. Parageneses of gold and silver tellurides at the Florencia gold deposit, Cuba. Int Geol Rev, 1988, 30: 294-306

26 Afifi A M, Kelly W C, Esene E J. Phase relations among tellurides, sulfides, and oxides: I. Thermochemical data and calculated equilibria. Econ Geol, 1988, 83: 377-394

27 Afifi A M, Kelly W C, Esene E J. Phase relations among tellurides, sulfides, and oxides: II. Applications to telluride-bearing ore deposits. Econ Geol, 1988, 83: 395-404

Open Access This article is distributed under the terms of the Creative Commons Attribution License which permits any use, distribution, and reproduction in any medium, provided the original author(s) and source are credited. 